Quebec Cooperative Study

of Friedreich's Ataxia

\title{
Taurine Decreases Lesion Severity In the Hearts of Cardiomyopathic Hamsters
}

\author{
JAMSHID AZARI, PETER BRUMBAUGH, ANDRÉ BARBEAU, RYAN HUXTABLE
}

SUMMARY: Cardiomyopathic Syrian hamsters develop necrotic lesions consequent upon calcium overload from 60 days of age onward. Taurine, given as a $0.1 \mathrm{M}$ solution in place of drinking water for one month prior to sacrifice of animals of initial age 35 days, decreased the severity of subsequently developing cardiac lesions by $40 \%$. Calcium concentration in the heart was decreased by 57\%. Magnesium and iron concentrations were unaltered. Taurine given in a similar manner for 4 months had a protective effect, decreasing lesion severity by $21 \%$ and calcium concentration by $35 \%$. Magnesium concentrations were increased by $12 \%$. Compared to randombred animals, cardiomyopathic hamsters

RESUME: Les hamsters syriens cardiomyopathiques développent des lésions nécrotiques subséquentes à une surcharge calcique à partir de la 60ème journée d'âge. La taurine, donnée en solution 0.1 Mau lieu d'eau potable et ce pendant un mois avant le sacrifice des animaux d'âge initial de 35 jours, a pu diminuer la sévérité des lésions cardiaques éventuelles par $40 \%$. La concentration cardiaque du calcium diminue de $57 \%$ alors que les concentrations de magnésium et de fer sont inchangées. La taurine donnée de façon semblable pour 4 mois a toujours un effet protecteur, diminuant la sévérité des lésions de $21 \%$ et la concentration du calcium de $35 \%$. La concentration du magnésium augmente de $12 \%$. Par comparaison aux animaux at one and two months of age have the same concentrations of calcium, magnesium and iron in the quadrants of the heart, except in the left ventricle, which has significantly higher concentration of calcium. Calcium concentrations are $70 \%$. $1320 \%$ and $2100 \%$ higher respectively in one month, two month and five month old animals. Five month old animals differ slightly but significantly in iron (17\% decrease) and magnesium concentrations (17\% increase).

Cardiomyopathic hamsters have insignificant differences in $\beta$-adrenergic receptor density compared to random-bred animals and have a significantly higher rate of taurine influx.

contrôles, les hamsters cardiomyopathiques ont la même concentration en calcium, magnésium et fer aux divers quadrants du coeur, sauf au ventricule gauche où la concentration en calcium est ignificativement élevee. Cette concentration de calcium est augmentée de $70 \%$, $1320 \%$ et $2100 \%$ respectivement à un mois, deux mois et cinq mois. À cinq mois il y a une légère modification significative du fer (diminution de 17\%) et du magnésium (augmentation de 17\%).

Ces hamsters cardiomyopathiques ne semblent pas montrer de différences dans la densité des récepteurs $\beta$-adrenergiques, mais le taux d'entrée (influx) de la taurine est significativement augmenté.

\section{INTRODUCTION}

There are a number of studies indicating that alterations in calcium uptake and content in the heart are closely related to the cardiac necrotic process (Bloom and Davis, 1974; Fleckenstein, 1975; Fleckenstein et al., 1974). The calcium overload may be caused by a number of mechanisms. Hartman and Booth (1960) have suggested that sympathetic overactivity secondary to lesions of the vagal nuclei may be one mechanism leading to myocardial damage. In such a case, the cardiac muscle is abnormally sensitive to adrenergic stimulation, which thus causes an increased flux of calcium across the cell membrane. In view of the crucial role different membrane systems such as sarcolemma, sarcoplasmic reticulum, and the mitochondria play in regulating calcium fluxes and the levels of intracellular calcium, various investigators have directed their attention to studying the role of these membranes in the pathogenesis of heart failure (Dhalla, 1974; Lindenmayer et al., 1971; Nayler et al., 1971). Decreased ability of the sarcoplasmic reticulum from hearts having different types of failure to accumulate calcium has been interpreted in terms of a defect in the process of excitation-contraction coupling (Dhalla et al., 1975; Muir et al., 1970; Sulakhe and Dhalla, 1971). There are also reports concerning changes in the ability of mitochondria from failing hearts to transport calcium (Dhalla, 1976; Sordahl et al., 1973). Defects in sarcolemma have received little attention due to the difficulties of isolating cardiac sarcolemma in a pure form. Recently, Singh and co-workers (1975) have shown that the sarcolemmal fraction obtained from cardiomyopathic hamsters in advanced stages of myopathy had lower activities of $\mathrm{Ca}^{2+}$-ATPase, 
$\mathrm{Mg}^{2+}$-ATPase, and $\mathrm{Na}^{+}, \mathrm{K}^{+}$-ATPase. Furthermore, activation of adenylate cyclase by epinephrine and sodium fluoride is markedly depressed. These membrane enzymes in particular participate in raising and lowering the intracellular level of ionized calcium. Thus, sarcolemmal abnormalities resulting in altered enzymatic activity may be responsible for calcium overload.

Although the precise mechanism(s) causing calcium overload is not clear, a number of pharmacological agents have been used to control the calcium overload. Dhalla (1976) has suggested heart failure resulting from calcium overload at early stages can be prevented by use of verapamil, propranolol or other agents capable of antagonizing calcium movement into the myocardium. Verapamil has been shown to be effective in controlling the calcium overload in cardiomyopathies (Jasmin and Bajusz, 1975). Taurine (2aminoethane sulfonic acid), is a naturally occurring $\beta$-amino acid which is abundant in the mammalian heart (Jacobsen and Smith, 1968). There are reports that taurine has a calcium modulating effect in the heart (Dolara et al., 1973; Guidotti et al., 1971). Taurine has been shown to increase the affinity of calcium for various intracellular structures (Dolara et al., 1973, Huxtable and Bressler, 1973). Experimentally, alterations in the level of taurine in the heart are rather hard to achieve (Awapara, 1956; Sturman, 1973). However, taurine concentrations increase in both human and experimental congestive heart failure (Huxtable and Bressler, 1974; Peterson et al., 1973). Based on the switterionic nature of taurine at physiological $\mathrm{pH}$, and its strong dipole moment, Huxtable (1976) has suggested taurine, through its interaction with the zwitterionic phospholipid structure of membrane, causes conformational changes by virtue of stabilizing charge separation. Such conformational changes result in alteration in ion flux and cation affinity. Thus, McBroom and Welty (1977) have shown taurine to decrease calcium overload in cardiomyopathic hamsters. This work is designed to establish the site for calcium overload, the involvement of other ions beside calcium in the cardiomyopathy, and the effect of taurine in controlling calcium overload and necrotic lesion severity in advance stages of cardiomyopathy.

\section{MATERIALS AND METHODS}

Male cardiomyopathic Syrian golden hamsters (CM) of the Bio 14.6 strain and random bred control hamsters (RB) were purchased from Telaco, Bar Harbor, Maine. ${ }^{3} \mathrm{H}-$ Taurine and ${ }^{3} \mathrm{H}$-dihydroalprenolol were purchased from New England Nuclear, Mass.

Heart Perfusion: Male hamsters weighing $100-120 \mathrm{~g}$ were used. One hour following heparin treatment $(2000 \mathrm{IU} / \mathrm{kg})$, hamsters were anesthesized with sodium nembutal (50 $\mathrm{mg} / \mathrm{kg}$ i.p.) and the heart removed and transferred to ice-chilled well-oxygenated $0.9 \%$ saline containing $5.5 \mathrm{mM}$ glucose. The aorta was cannulated and the hearts perfused retrogradely at a flow rate of $4 \mathrm{ml} / \mathrm{min}$ in a non-recirculating system with oxygenated Kreb-Henseleit bicarbonate buffer ( $\mathrm{pH}$ 7.4) containing $5.5 \mathrm{mM}$ glucose. After five minutes of perfusion, the buffer was switched to one containing $\left[{ }^{3} \mathrm{H}\right]$ taurine $(25 \mu \mathrm{M}$; $0.05 \mu \mathrm{Ci} / \mathrm{ml}$ ) and substrate perfusion continued for $4 \mathrm{~min}$, followed by a 5 min washout period. Influx was determined in two ways: (i) measurement of the difference in radioactivity of the perfusate and effluent, and (ii) measurement of $\left[{ }^{3} \mathrm{H}\right]$ taurine remaining in the heart following washout. Hearts were homogenized in 8 volumes of $5 \%$ trichloroacetic acid and centrifuged at $40,000 \mathrm{xg}$ for $20 \mathrm{~min}$. The radioactivity in the deproteinized supernatant was determined by liquid scintillation counting.

Spectral Analysis: $\mathrm{CM}$ and RB animals were sacrificed by decapitation. Hearts were removed and washed in $0.9 \%$ saline solution containing $5.5 \mathrm{mM}$ glucose. Atria, right and left ventricles were dissected, washed and blot-dried before transfer to preweighed calcium-free volumetric flasks. The samples were digested for one hour in $65 \%$ ultrapure nitric acid (EM Laboratories, Elmford, New York) on a steam bath. Sufficient ionization buffer was added to make the final solution $1000 \mathrm{ppm}$ cesium. After being cooled, the samples were diluted with distilled deionized water. Precipitated proteins were filtered, and the solution analyzed by conventional atomic absorption spectrophotometry with a Varian AA5. An air/acetylene flame was used for iron and a nitrous oxide/acetylene flame for calcium and magnesium. The analytical wave lengths used were $422.7,285.2$, and $248.3 \mathrm{~nm}$ respectively for calcium, magnesium, and iron.

Taurine Analysis: Animals were sacrificed by decapitation and hearts removed, washed in saline, and dissected. After being transferred to pre-weighed centrifuge tubes, the tissues were diluted 1:10 with $3.5 \%$ 5sulfosalicylic acid, sonicated to homogenity, contrifuged, and the supernatant analyzed for taurine on a Beckman model $118 \mathrm{C}$ amino acid analyzer.

Receptor Binding Assay: Tissue from each heart ventricle was homogenized with a polytron (Brinkman; setting 5 for $30 \mathrm{sec}$ ) to make a $2.5 \%$ homogenate in $0.05 \mathrm{M} \mathrm{Na}^{+}-\mathrm{K}^{+}$phosphate buffer ( $\mathrm{pH}$ 7.4). The homogenate was passed through several layers of cheese cloth, and centrifuged at $48,000 \mathrm{~g}$ for $20 \mathrm{~min}$ in a Sorvall RC2-B centrifuge. The supernatant was measured and discarded. The pellets were suspended in $\mathrm{Na}^{+}-\mathrm{K}^{+}$phosphate buffer in a volume equal to that of the discarded supernatant. The suspension was rehomogenized for $5 \mathrm{sec} \beta$ Adrenergic receptors were assayed by the method of Bylund and Snyder (1976). Tissue homogenated containing $80 \mu \mathrm{g}$ protein were incubated for 30 min at $25^{\circ} \mathrm{C}$ in $2 \mathrm{ml}$ of $0.05 \mathrm{M} \mathrm{Na}^{+}-\mathrm{K}^{+}$ phosphate buffer containing $0.25 \mu \mathrm{M}$ ${ }^{3} \mathrm{H}$-dihydroalprenolol $(58 \mathrm{Ci} / \mathrm{mmole}$, NEN) in the presence and absence of $0.1 \mu \mathrm{M}(-)$-propanolol. The reaction was terminated by vacuum filtration through $G F / B$ glass fiber filters followed by four $5 \mathrm{ml}$ rinses with buffer at $25^{\circ} \mathrm{C}$. Bound ${ }^{3} \mathrm{H}-\mathrm{DHA}$ retained on the filter was extracted in 9 $\mathrm{ml}$ of a toluene-based scintillation cocktail and radioactivity counted. Specific ${ }^{3} \mathrm{H}-\mathrm{DHA}$ binding was defined as the binding displaceable by $0.1 \mu \mathrm{M}$ (-)-propranolol.

Protein Determination: Protein determination for receptor binding studies of the ventricle were performed by the method of Lowry et al. (1951). 
Sample Preparation for Histology: Animals were sacrificed by decapitation, hearts rapidly removed, and transferred to ice chilled $0.9 \%$ saline. The hearts were perfused through the aorta with cold saline to remove the blood, and sectioned transversely into upper and lower halves. Each time an alternating half was fixed in $10 \%$ buffered-formalin. The other half was used for ion and taurine determinations. Hematoxilin-eosin stained $6 \mu$ sections were prepared from paraffinembedded tissues. Von-Kossa stained sections were prepared for further confirmation of calcium deposition in the myocardium. The microscopic slides were evaluated for calcium deposition in a blind study. Grading was based on $0-4^{+}$scale with $4^{+}$ representing the highest level.

Calculation: Statistical analyses were performed on Wang Series 700 Programmable Calculator. All values are expressed as mean \pm standard error of mean (SEM) and a difference with probability of $<0.05$ as calculated by student's unpaired ' $t$ ' test was considered significant.

\section{RESULTS}

\section{Cation Alterations in}

\section{Cardiomyopathy}

Cardiac lesion in cardiomyopathic Syrian hamsters develop from approximately the 60th day of life onwards.
We have, therefore, used animals of 30 - 40 days of age as prelesion, and animals 60 - 70 days of age as postlesion to elucidate which changes precede the appearance of lesions and which changes occur after the appearance of lesions.

Cation concentrations in the quadrants of the heart are illustrated in Table I for pre- and post-lesion animals. Compared to non-cardiomyopathic random-bred animals, prelesion hamsters have higher calcium oncentrations in the left ventricle only. After lesioning, there is a marked increase in left ventricular calcium, but again, the atria and right ventricle are unaffected. Magnesium and iron concentrations are unchanged in cardiomyopathic hamsters relative to control animals.

It seems unlikely that the calcium overload is due to increased $\beta$-adrenergic receptor density. The binding of a specific $\beta$-adrenergic ligand, ${ }^{3} \mathrm{H}$-dihydroalprenolol, is increased by some $50 \%$ on a per $\mathrm{mg}$ protein basis, but when comparison is made on a per gram heart, or per whole heart basis, no significant difference is apparent, although cardiomyopathic hearts have somewhat higher values (Table 2).

\section{Taurine in the Cardiomyopathic Heart}

In prelesion animals, taurine levels tend to be higher than in control animals. The increase is statistically significant only in the left atrium (Table 3). The general increase in taurine content is consistent with the higher influx rate of taurine observed in the Langendorff-perfused isolated heart (Table 4).

\section{Protective Effect of Taurine on \\ Cardiomyopathic Lesions}

Both pre- and post-lesion animals showed decreases in cardiac calcium concentrations of $50-60 \%$ when maintained on $0.1 \mathrm{M}$ taurine in drinking water for one month (Tables 5 and 6). The concentrations of iron and magnesium were unaltered (data not shown). This treatment caused the cardiac taurine content to be slightly but significantly elevated (Table 5).

Oral taurine given for one month, was also effective in decreasing the subsequent severity of lesion development by some $40 \%$ (Table 5). The system used to determine lesion severity is graded as $0,1+, 2+, 3+$, and $4+$. The protective effect of taurine persists for several months, being still apparent after four months (Table 6). Although the lesions were more extensive in animals of this age, the taurine-treated animals had lesions less severe than those in the untreated animals. Taurine content of hamster heart normally falls with age (e.g.

TABLE 1

Regional Cation Concentrations in Hearts

From 30 - 40 Day Old and 60 - 70 Day Old Hamsters

\begin{tabular}{lllcccc}
\hline & $\begin{array}{c}\text { Age } \\
\text { (days) }\end{array}$ & LOCATION & $\begin{array}{c}\text { Wet Tissue } \\
\text { Weight (mg) }\end{array}$ & Ca & $\begin{array}{c}\mu \mathbf{g} / \mathbf{g} \text { Tissue } \\
\text { Mg }\end{array}$ & Fe \\
\hline \multirow{2}{*}{ RB } & \multirow{2}{*}{$30-40$} & right \& left atria & $8.7 \pm 0.4$ & $45 \pm 5$ & $223 \pm 23$ & N.D. \\
& & right ventricle & $31.5 \pm 1.8$ & $68 \pm 6$ & $253 \pm 1$ & $45 \pm 6$ \\
& & left ventricle & $124.5 \pm 4.0$ & $40 \pm 3$ & $233 \pm 21$ & $41 \pm 3$ \\
CM & \multirow{2}{*}{$30-40$} & right \& left atria & $9.4 \pm 0.5$ & $59 \pm 11$ & $239 \pm 12$ & N.D. \\
& & right ventricle & $40.0 \pm 3.5$ & $68 \pm 5$ & $247 \pm 1$ & $39 \pm 2$ \\
& & left ventricle & $133.0 \pm 5.6$ & $68 \pm 8^{\mathrm{a}}$ & $246 \pm 3$ & $51 \pm 2$ \\
RB & \multirow{2}{*}{$60-70$} & right \& left atria & $13.4 \pm 1.0$ & $67 \pm 6$ & $205 \pm 4$ & $54 \pm 2$ \\
& & right ventricle & $54.2 \pm 1.0$ & $52 \pm 2$ & $236 \pm 2$ & $56 \pm 1$ \\
& & left ventricle & $208.0 \pm 6.5$ & $36 \pm 0$ & $221 \pm 3$ & $46 \pm 2$ \\
CM & \multirow{2}{*}{$60-70$} & right \& left atria & $14.0 \pm 1.5$ & $81 \pm 8$ & $197 \pm 1$ & $61 \pm 7$ \\
& & right ventricle & $43.8 \pm 1.0$ & $63 \pm 4$ & $222 \pm 2$ & $56 \pm 2$ \\
& & left ventricle & $190.1 \pm 5.8$ & $510 \pm 93^{\mathrm{b}}$ & $217 \pm 5$ & $47 \pm 0$ \\
\hline
\end{tabular}

${ }^{\mathrm{b}} \mathrm{p}<.025,{ }^{\mathrm{b}} \mathrm{p}<.050$

N.D.: Not detectable

Data shown as means \pm SEM for four hearts per group. 
TABLE 2

$\beta$-Adrenergic Receptor Binding

in Hearts from 90 Day Old Hamsters

\begin{tabular}{lccccc}
\hline & $\begin{array}{c}\text { Heart: Body } \\
\text { Ratio } \mathbf{~ 1 0 ~}\end{array}$ & $\begin{array}{c}\text { Wet Heart Wt } \\
(\mathbf{m g})\end{array}$ & mg protein & fmole/3H-dihydroalprenolol bound \\
g tissue & heart \\
\hline RB & $3.3 \pm 0.1$ & $395 \pm 9$ & $6.0 \pm 0.3$ & $334.8 \pm 32.5$ & $131.4 \pm 10.7$ \\
CM & $4.0 \pm 0.1$ & $533 \pm 20$ & $8.5 \pm 1.0^{\mathrm{a}}$ & $371.2 \pm 26.6$ & $197.4 \pm 34.8$ \\
\hline
\end{tabular}

${ }^{\mathrm{a} p}<0.05$

Data shown as mean \pm SEM for five hearts per group.

compare CM hamsters without taurine in Table 5 and Table 6). When animals are maintained on drinking water containing taurine, however, cardiac taurine content does not decrease over the 4 month treatment period. In $C M$ hamsters with advanced cardiomyopathy, the cardiac content of calcium is increased to an even greater degree, and changes also appear in the concentrations of other cations. Magnesium levels are significantly elevated, and iron levels significantly depressed, when compared to RB hamsters (Table 6). We conclude that taurine treatment has no effect on the changes in magnesium content but antagonizes the increase in calcium and the decrease in iron.

\section{DISCUSSION}

A major defect in the cardiomyopathic Syrian hamster is an increased permeability of the heart cell membrane to calcium. The resultant calcium overload appears to be at least partially responsible for the energy depletion, and necrotic lesions that develop in the hearts of these animals. Although genetic in origin, the cardiomyopathic lesions do not develop until around 60 days after birth. Animals of 30 days of age, therefore, may be referred to as pre-lesion, and animals of 60 days and upwards as post-lesion. In hamsters at the prelesioning stage, no difference in calcium concentration is found between the left and right ventricles. However, compared to random-bred control animals, the calcium content is significantly elevated in the left ventricle. The excess of calcium massively increases with the development of lesions. In old animals (120 days of age), calcium levels are even more increased over those at 60

TABLE 3

Regional Concentration of Taurine

in Hearts of $30-40$ Day Old Hamsters

\begin{tabular}{lcc} 
& \multicolumn{2}{c}{ Taurine $(\mu$ mole $/ \mathbf{g}$ wet wt $)$} \\
\cline { 2 - 3 } LOCATION & RB & CM \\
\hline right atrium & $26.4 \pm 3.3$ & $36.8 \pm 9.3$ \\
left atrium & $26.7 \pm 1.7$ & $33.5 \pm 1.0^{a}$ \\
right ventricle & $36.3 \pm 5.9$ & $35.0 \pm 2.0$ \\
left ventricle & $26.9 \pm 3.6$ & $29.4 \pm 1.8$ \\
TOTAL TAURINE & $28.5 \pm 2.3$ & $30.8 \pm 2.8$ \\
\hline
\end{tabular}

${ }^{\mathrm{a}} \mathrm{p}<0.025$

Data shown as mean \pm SEM for four hearts per group.

TABLE 4

Rate of Taurine Influx

\begin{tabular}{lcccc}
\hline & $\begin{array}{c}\text { Wet Heart } \\
\text { Weight (g) }\end{array}$ & $\begin{array}{c}\text { Dry Heart } \\
\text { Weight (g) }\end{array}$ & $\begin{array}{c}\text { INFLUX RATE } \\
\text { nmole/min/g } \\
\text { wet }\end{array}$ & $\begin{array}{c}\text { nmole/min/g } \\
\text { dry wt }\end{array}$ \\
\hline RB & $393 \pm 7$ & $86 \pm 2$ & $3.1 \pm 0.2$ & $14.0 \pm 0.8$ \\
CM & $411 \pm 11$ & $84 \pm 3$ & $4.6 \pm 0.3^{*}$ & $22.6 \pm 1.8^{*}$ \\
\hline
\end{tabular}

$* \mathrm{p}<0.005$

The isolated hearts from 70 - 80 day old hamsters were perfused by Langendorff technique. The hearts were perfused at a flow rate of $4 \mathrm{ml} / \mathrm{min}$ with Krebs-Henseleit buffer for five minutes. Then buffer was switched to one containing $25 \mu \mathrm{M}$ taurine $(0.05 \mu \mathrm{Ci} / \mathrm{ml})$ and perfused for five minutes. Following the perfusion with substrate, there was a five minute washout. The rate of influx was determined from the radioactivity remaining in the heart. Data shown as mean \pm SEM for five hearts in each group.

days. Prior to the appearance of lesions, and immediately after the appearance of lesions, the cations iron and magnesium are not altered in concentration compared to control animals. However, in the old animals, magnesium concentrations are elevated, and iron concentrations depressed.

Taurine concentrations tend to be higher in the heart of animals prior to the development of lesions when compared to control animals, although this increase is significant only in the right ventricle. In general, alterations in cardiac taurine concentrations are not easy to achieve. However, taurine concentrations are markedly elevated in hearts in congestive failure in both animals and humans (Huxtable and Bressler, 1974; Peterson et al., 1973). It has been shown that the $\beta$ adrenergic agonist, isoproterenol, sti- 
mulates the rate of influx of taurine in the isolated perfused rat heart (Huxtable and Chubb, 1977). Adrenergic stimulation of influx is probably responsible for the elevations in cardiac taurine concentrations found in congestive failure. An increased rate of taurine influx into the heart of cardiomyopathic hamsters is also observed (Table 4), and this may also be due to increased adrenergic tone. The fact that in $\mathbf{3 0}$ day old animals taurine concentration is only marginally elevated relative to control hamsters suggests that taurine efflux is probably also somewhat increased.

When animals in the pre-lesioning stage are maintained on $0.1 \mathrm{M}$ taurine solution in place of tap water, calcium accumulation is markedly decreased in the heart after one month. In addition, areas of calcium-induced necrosis are also markedly diminished. A modest increase in cardiac taurine concentration accompanies these effects of taurine (Table 5). When animals are maintained on taurine solution for 4 months, the protective effects of taurine still persist (Table 6). Calcium accumulation and degree of lesioning are decreased, but magnesium and iron concentrations are unaffected, indicating that the effects of taurine are peculiar to calcium.

These findings confirm and extend previous studies, in which when taurine was given orally for 1 month prior to the appearance of lesions, there was decreased accumulation of calcium by the heart (McBroom and Welty, 1977).

TABLE 5

Effect of Oral Taurine on Lesion Development in the Hearts of Cardiomyopathic Hamsters

Water Taurine

(10)

(18)

\begin{tabular}{lcc}
\hline $\begin{array}{l}\text { Serum taurine } \\
(\mu \mathrm{mole} / \mathrm{ml})\end{array}$ & $0.64 \pm 0.05$ & $0.80 \pm 0.07$ \\
$\begin{array}{l}\text { Cardiac taurine } \\
(\mu \mathrm{mole} / \mathrm{dry} \text { weight })\end{array}$ & $133.8 \pm 5.7$ & $154.5 \pm 5.8^{\mathrm{a}}$ \\
$\begin{array}{l}\text { Cardiac calcium } \\
(\mu \mathrm{g} / \mathrm{g} \text { tissue })\end{array}$ & $814 \pm 113$ & $353 \pm 74^{\mathrm{b}}$ \\
Lesion score & $3.0 \pm 0.4$ & $1.8 \pm 0.3^{\mathrm{b}}$ \\
\hline
\end{tabular}

$\mathrm{a}=\mathrm{p}<0.025$

$\mathrm{b}=\mathrm{p}<0.010$

Cardiomyopathic hamsters 30 - 40 days old were placed on $0.1 \mathrm{M}$ taurine or distilled water as drinking water for one month prior to sacrifice. Data shown as mean $\pm S E M$.

The association of decreased calcium accumulation, and decreased severity of lesions after oral taurine treatment suggests that taurine is having a protective effect due to a modulatory action on calcium entry. It has recently been demonstrated that taurine increases the affinity for calcium of a calcium binding site on the heart cell sarcolemma, thus bringing about a lowering of free calcium levels within the cell (Chovan et al., 1979).

Taurine is a relatively nontoxic substance - a normal constituent of human diet - which has potential use in the treatment of hyperkinetic hearts, or hearts exhibiting defects in calcium regulation. One such cardiac disorder may be the cardiomyopathy associated with Friedreich's ataxia. A common feature of Friedreich's ataxia is the presence of cardiomyopathy. Hearts from Friedreich's ataxia patients can show severe and diffuse intracellular fibrosis, and some areas of intracellular calcification (Sanchez-Casis et al., 1976). The actions of taurine on the cardiomyopathy of cardiomyopathic Syrian hamsters may serve as a paradigm for similar cardiomyopathies in humans.

\section{ACKNOWLEDGEMENTS}

This work was supported by USPHS grant HL 19394 and by a grant from l'Association Canadienne de l'Ataxie de Friedreich.

\section{REFERENCES}

AWAPARA, J. (1956) The taurine concentration of organs from fed and fasted rats. Journal of Biological Chemistry 218 571576.

\section{TABLE 6}

Effect of Taurine on Cation Concentrations and Lesion Score in Advanced Stages of Cardiomyopathy

\begin{tabular}{lccccc} 
& Ca & Mg & Fe & $\begin{array}{c}\mu \text { mole/g dry wt } \\
\text { Taurine }\end{array}$ & $\begin{array}{c}\text { Lesion } \\
\text { Score }\end{array}$ \\
\hline RB & $172 \pm 18$ & $858 \pm 11$ & $206 \pm 2$ & $105 \pm 10$ & 0.0 \\
CM WITHOUT & & & & & \\
TAURINE & $3775 \pm 221$ & $1008 \pm 8^{\mathrm{a}}$ & $171 \pm 4^{\mathrm{b}}$ & $107 \pm 6$ & $3.3 \pm 0.5$ \\
CM PLUS TAURINE & $2472 \pm 543$ & $1006 \pm 22^{\mathrm{a}}$ & $191 \pm 4^{\mathrm{b}}$ & $142 \pm 11^{\mathrm{b}}$ & $2.6 \pm 0.4$ \\
\hline
\end{tabular}

$\mathrm{a}=\mathrm{p}<0.001$

$\mathrm{b}=\mathrm{p}<0.025$

The cardiomyopathic hamsters ( 30 - 40 days old) were placed on taurine $(0.1 \mathrm{M})$ as their drinking water for four months, prior to sacrifice. At the end of the four months, the animals were sacrificed, and the hearts were removed. Data are shown as mean $\pm S E M$ for four hearts in $\mathrm{RB}$ and $\mathrm{CM}$ without taurine group and six hearts in $\mathrm{CM}$ plus taurine group. 
BLOOM, S. and DAVIS, D. (1974). Isoproterenol myocytolysis and myocardial calcium. In "Myocardial Biology", N.S. Dhalla, ed., pp. 581-590. Baltimore University Park Press.

BYLUND, D. and SNYDER, S. (1976), $\beta$ Adrenergic receptor binding in membrane preparation from mammalian brain. Molecular Pharmacology 12 568-580.

CHOVAN, J.P., KULAKOWSK1, E.C., BENSON, B.W. and SCHAFFER, S.W. (1979) Taurine enhancement of calcium binding to rat heart sarcolemma. Biochim. Biophys. Acta 551 129-136.

DHALLA, N.S. (1974) Defects in calcium regulatory mechanisms in heart failure. In "Myocardial Biology", N.S. Dhalla, ed., pp. 521-534. Baltimore: University Park Press.

DHALLA, N.S. (1976) Involvement of membrane systems in heart failure due to intracellular calcium overload and deficiency. Journal of Molecular and Cellular Cardiology 8 661-667.

DHALLA, N.S., TOMLINSON, C.W., YATES, J.C., LEE, S.L., VARLEY, K.G., BOROWSKI, I.F.M. and BARWINSKY, J. (1975) Role of mitochondrial calcium transport in failing heart. In "Basic Function of Cations in Myocardial Activity", A. Fleckenstein and N.S. Dhalla, eds., pp 177-187. Baltimore: University Park Press.

DOLARA, P., AGRESTI, A., GIOTTI, A. and PASQUINI, G. (1973) Effect of taurine on calcium kinetics of guinea pig hearts. European Journal of Pharmacology 24 352358.

FLECKENSTEIN, A. (1975) Metabolic factors in the development of myocardial necrosis and micro-infarcts. Triangle 14 27-36.

FLECKENSTEIN, A., JANKE, J. DORING, H.J. and LEDER, O. (1974) Myocardial fiber necrosis due to intracellular $\mathrm{Ca}$ overload - a new principle in cardiac pathophysiology. In "Myocardial Biology", N.S. Dhalla, ed., pp. 563-580. Baltimore: University Park Press.
GUIDOTTI, A. BADIANI, G. and GIOTTI, A. (1971) Potentiation by taurine of inotropic effect of strophanthin $K$ on guinea pig isolated auricles. Pharmacol. Res. Commun. 3 29-38.

HARTMAN, J.W. and BOOTH, R.W. (1960) Friedreich's ataxia: A neurocardiac disease. American Heart Journal 60 716-720.

HUXTABLE, R. (1976) Metabolism and function of taurine in the heart. In "Taurine", R. Huxtable and A. Barbeau, eds., pp. 99-119. New York: Raven Press.

HUXTABLE, R, and BRESSLER, R. (1973) Effect of taurine on a muscle intracellular membrane. Biochimica et Biophysica Acta 323 573-583.

HUXTABLE, R. and BRESSLER, R. (1974) Taurine concentration in congestive heart failure. Science 184 1187-1188.

HUXTABLE, R. and CHUBB, J. (1977) Adrenergic stimulation of taurine transport by the heart. Science 198 409-4II.

JACOBSEN, J.G. and SMITH, L.H. (1968) Biochemistry and physiology of taurine and taurine derivatives. Physiology Review 48 424-511.

JASMIN, G, and BAJUSZ, E. (1975) Prevention of myocardial degeneration in hamsters with hereditary cardiomyopathy. In "Pathophysiology and Morphology of Myocardial Cell Alterations", A. Fleckenstein and G. Rona, eds., pp. 219-229. Baltimore: University Park Press.

LINDENMAYER, G.E., SORDAHL, L.A., HARIGAYA, S., ALLEN, J.C., BESCH, JR., H.R. and SCHWARTZ, A. (197I) Some biochemical studies on subcellular systems isolated from fresh recipient human cardiac tissue obtained during transplantation. American Journal of Cardiology 27 227-283.

LOWRY, O., ROSEBROUGH, N., FARR, A. and RANDALL, R. (1951) Protein measurement with folin phenol reagent. Journal of Biological Chemistry 193 265-275.
McBROOM, M.J. and WELTY, J.D. (1977) Effects of taurine on heart calcium in the cardiomyopathic hamster. Journal of Molecular and Cellular Cardiology 9 853-858.

MUIR, J.R., DHALLA, N.S., ORTEZA, J.M. and OLSON, R.E. (1970) Energy linked calcium transport in subcellular fractions of the failing rat heart. Circulation Research 26 429-438.

NAYLER, W.G., STONE, J., CARSON, V. and CHIPPERFIELD, D. (1971) Effect of ischemia on cardiac contractility and calcium exchangeability. Journal of Molecular and Cellular Cardiology 2 125-143.

PETERSON, M.B., MEAD, R.J. and WELTY, J.D. (1973) Free amino acids in congestive heart failure. Journal of Molecular and Cellular Cardiology 5 139-147.

SANCHEZ-CASIS, G., COTÉ, M. and BARBEAU, A. (1976) Pathology of the heart in Friedreich's ataxia: Review of the literature and report of one case. The Canadian Journal of Neurological Sciences 3 323-328.

SINGH, J.N., DHALLA, N.S., MENAMARA, D.B., BAJUSZ, E. and JASMIN, G. (1975) Membrane alteration in failing hearts of cardiomyopathic hamsters. In "Pathophysiology and Morphology and Myocardial Cell Alterations", A. Fleckenstein and G. Rona, eds., pp. 259-268. Baltimore: University Park Press.

SORDAHL, L.A., McCOLLUM, W.B., WOOD, W.G. and SCHWARTZ, A. (1973) Mitochondria and sarcoplasmic reticulum function in cardiac hypertrophy and failure. American Journal of Physiology 224 497502.

STUR MAN, J.A. (1973) Taurine pool size in the rat: Effect of vitamin B6 deficiency and high taurine diet. Journal of Nutrition 103 15661580.

SULAKHE, P.V. and DHALLA, N.S. (1971) Excitation-contraction coupling in heart VII. Calcium accumulation in subcellular particles in congestive heart failure. Journal of Clinical Investigation 50 1019-1027. 